\title{
UK moves closer to free market for research funding
}

London. Government and industrial laboratories would be allowed to compete for funding from the British research councils under a new proposal from the Advisory Board for the Research Councils. The councils would also be encouraged to pool their resources to support worthwhile research in biotechnology.

The seven-man subcommittee that produced the report* included Sir Mark Richmond, chairman of the Science and Engineering Research Council; Tom Blundell, secretary of the Agricultural and Food Research Council; Dai Rees, secretary of the Medical Research Council; and Eileen Buttle, secretary of the Natural Environment Research Council. Such senior backing from within the research councils practically ensures that the proposal will be implemented. It also has the support of the science minister, William Waldegrave, who says that "it is entirely consistent with our policy on opening up an internal market for government-funded research and development".

The report would overturn a longstanding policy that each research council should stick to its own area, although the charters of each council do not specify where the research they fund should be carried out. Some administrative hurdles must also be cleared; the SERC, for example, hopes to change its rules to allow for external bids.

The opening of research council funds to proposals from industrial and government laboratories is likely to upset university researchers, who fear that money will be siphoned off for applied research. "Funds for basic research are so thin anyway that it is madness to dilute them further by giving them to people to do nearmarket research", says Derek Roberts, provost of University College, London. Research funds are already expected to be strained by applications from the new universities - until this year the polytechnics - many of which have said they intend to do more basic research. On the other hand, the report suggests that academics have access to other sources of government and industrial funding, although few think this will happen.

The government laboratories have welcomed the move but are not saying to what extent they will take advantage of this new funding source. Many have become agencies, which makes them responsible for generating their own income. Although this

\section{Ludwig estate to support research}

Washington. Six US institutions with cancer research programmes have inherited the bulk of the fortune of Daniel K. Ludwig, a reclusive cancer philanthropist who died in late August at the age of 95

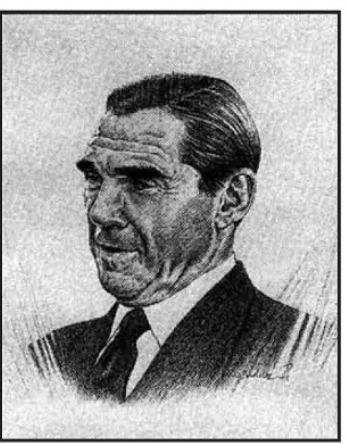

Daniel K. Ludwig and whose estate was recently estimated at $\$ 1.2$ billion. But the known amount $\$ 46$ million - is far below what most would have expected from a man who 20 years ago created a string of cancer research institutes throughout Europe with a present endowment of $\$ 700$ million.

It will be 21 years, in fact, before the institutions mentioned in Ludwig's will the Massachusetts Institute of Technology, Memorial Sloan-Kettering Cancer Center and the medical schools of Harvard
University, the Johns Hopkins University, Stanford University and the University of Chicago - receive most of Ludwig's bequest, which consists mostly of domestic real estate. The will stipulates that Ludwig's property be placed in the Virginia and D.K. Ludwig Fund for Cancer Research, whose trustees will distribute investment income at their discretion to the six beneficiaries. After 21 years, the remaining money will be divided by the trustees among the six beneficiaries.

Ludwig apparently disposed of most of his fortune in 1971, when he used his considerable European assets to create the Ludwig Institute for Cancer Research. The institute includes 11 branches in eight countries; each branch supports several investigators, who focus on one biological problem associated with cancer.

Ludwig, who gained most of his wealth from shipping, mining and real estate, never suffered from cancer, nor did any of his close relatives, according to his friend and former physician Hugh Butt. Ludwig supported cancer research, Butt says, because it is "the most feared disease and affects children as well as adults".

Traci Watson makes them more predatory, it also raises the costs of research as there is no govern ment subsidy for wages and overhead. Without a good deal of creative accounting, the universities and research council institutes will be able to give better value for money.

Explicit funding by more than one council is permitted but not widespread. It has happened most easily where the missionorientated research councils have shown an interest in molecular biology. However, most academics acknowledge that a proposal to a single council can be broadened if it contains research attractive to a larger audience.

As the title of the proposal suggests, the decision to admit government and industrial laboratories is particularly important for biotechnology research, a subject in which all the research councils and several industries have an interest. Attempts to coordinate biotechnology over the past decade have been frustrated by a failure to agree on intercouncil programmes, and the freeing of funding channels is expected to strengthen the current coordinating body, the Biotechnology Joint Advisory Board.

Ian Mundell

* Report of the ABRC Biotechnology Subcommittee Advisory Board for the Research Councils, 5B3 Sanctuary Buildings, Great Smith Street, London SW1P 3BT, telephone 071-925-5966.

\section{Small businesses to get bigger slice of US research pie}

Washington. The US Congress last week agreed to increase the share of federal research dollars going to small businesses, part of a government-wide trend towards more funding for research aimed at commercial products. The legislation will more than double the size of the Small Business Innovation Research (SBIR) programme over the next five years, from $\$ 430$ million a year to more than $\$ 1$ billion by 1997 .

Although industrial researchers welcome the increase, university scientists are less enthusiastic. The reason is simple: the money will come from budgets that finance their projects.

The SBIR programme currently gets its funding by taking 1.25 per cent from each federal agency that spends more than $\$ 100$ million on research, including the National Institutes of Health, the National Science Foundation and the National Aeronautics and Space Administration. Beginning this month, that share will increase to 1.5 per cent, eventually reaching 2.5 per cent in 1997.

At NSF, for example, that means its SBIR programme will grow this year from $\$ 22$ million to about $\$ 27$ million and that $\$ 5$ million less will be available for traditional grants to academic scientists. NSF officials may not like the involuntary shift in funds, but they say that the programme is too popular to oppose. Christopher Anderson 